\title{
The Relationship Between Malaysian Supermarket In-Store Shopping Experiences and Positive Word-of-Mouth
}

\author{
Phang Ing ${ }^{1}$, Liew Ru Ven $\operatorname{Ivan}^{1} \&$ Zaiton Osman ${ }^{1}$ \\ ${ }^{1}$ Faculty of Business, Economics and Accountancy, Universiti Malaysia Sabah, Malaysia \\ Correspondence: Phang Ing, Faculty of Business, Economics and Accountancy, Universiti Malaysia Sabah, Jalan \\ UMS, 88400 Kota Kinabalu, Sabah, Malaysia. E-mail: gracep@ums.edu.my
}

Received: April 10, 2019 Accepted: May 5, $2019 \quad$ Online Published: May 21, 2019

doi:10.5539/ijms.v11n2p115 URL: https://doi.org/10.5539/ijms.v11n2p115

\begin{abstract}
Attitudinal loyalty such as customers' willingness to spread positive words of mouth has received less attention compared to behavioural loyalty (e.g., reptronage intention) in retail studies, particularly in the context of supermarket. It is argued that supermarket consumers should be willingly share positive words of mouth when they are satisfied. The effect of Malaysian supermarket in-store experiences (convenience, merchandise value, internal shop environment, interaction with staff, merchandise variety, presence interaction with other customers, in-shop emotion) on customer satisfaction and mediating effect of customer satisfaction on the relationship between in-store experiences and positive WoM were examined. The results show significant relationship between customer satisfaction and willingness to spread positive WoM. Convenience and in store emotion have significant relationships with customer satisfaction, while the other in-store experiences have no significant effects on satisfaction. Customer satisfaction played mediation roles between the relationships between convenience, merchandise variety, interaction with staff and in store emotion with positive WoM. The findings provide useful insights to Malaysian supermarket retailers in understanding their target markets to encourage more positive WoM.
\end{abstract}

Keywords: in-store shopping experiences, WoM, customer satisfaction

\section{Introduction}

The Malaysian retail sector recorded RM 192 million in sales in 2017 with $98 \%$ contributed by store-based sales (Euromonitor International, 2018a). The steady growth in the retail markets are mainly supported by the Malaysian middle-income population as they are willing to spend more on non-discretionary goods with their disposable incomes (Euromonitor International, 2018b). Despite the strong presence of home-grown and foreign retail corporations, the Malaysian retail industry is considered fragmented. Different from developed nation, traditional grocery retailers and non-grocery retailers located in the rural areas and neighbourhood districts still hold major shares in the local Malaysian retail market (Euromonitor International, 2018a). Importantly, despite the technological advancement in online retailing sector and changes in consumer buying pattern, the number of grocery stores still experiences an increasing trend in 2017, implying that store-based conventional grocery formats such as hypermarkets, supermarkets, and minimarkets are still highly relevant in Malaysia.

Majority of the retail businesses, particularly the grocery retailers, rely heavily on consumer patronage on daily basis. Consumers in the urban area prefer grocery stores with hassle-free navigation floorplan and offer a wide-ranging merchandise offering as convenience is prioritize in their busy lifestyles. These time-starved urban consumers also visit neighbourhood supermarkets, convenience stores, and online grocery retailers. By keeping approximately 30,000 SKUs (stock keeping unit; Levy, Weitz, \& Grewal, 2015), conventional neighbourhood supermarket is found to a popular option compared to large hypermarket as it allows the consumers to restock their daily grocery needs in small quantity on daily basis rather than the latter as they need to do it on weekly basis at larger quantity (Euromonitor International, 2018a). Price-sensitive consumers want hassle-free grocery shopping experience by not leaving their neighbourhood as the traditional grocers situated throughout the country carry most of the needed household products selling at reasonable prices. Supermarkets differentiate themselves from other food retailers with the following aspects: offering fresh perishables, targeting green and ethnic consumers, providing better value with its private-label merchandise, and provide excellent in-store experience. 
However, maintaining loyal customer still posts a great challenge to many grocery retailers as brand switching is getting common among consumers due to stiff market competition. The tougher economic environment in Malaysia has posed more challenges for local retailers. Customer loyalty is known to generate benefits such as repeat patronage, positive word-of-mouth (WoM), and resistant to competitors' enticement to businesses (Dick \& Basu, 1994; Rowley, 2005). However, many retail consumers felt relationship is meant for the people around them rather than for brand (Freeman, Spenner, \& Bird, 2012). What worrying more is that grocery retailers such as supermarkets are reported to hardly withstand the stiff retail competition due to changes in consumer shopping behaviours where weekly shopping at the big supermarkets are shift to ad hoc purchases at convenience stores (Ruddick, 2015). Physical price survey is no longer applicable with the advancement of online search engines and price war initiated by supermarkets has caused major shifts in customer loyalty as online info is just a click away. Malaysian retailers, specifically supermarkets are findings it difficult to attract new customers while retaining existing customers as customers are spoilt with a wide range of stores that carry similar products as the supermarkets did. Besides repatronage issue, lacking of points of differentiation among the supermarkets leaves no reason for consumers to share positive WoM with other customers. Importantly, it is "expected that what constitutes the in-store customer shopping experience in supermarkets today are likely to differ from those reported in previous studies a decade ago" (Terblanche, 2018, p. 49). The study of Malaysian retail market particularly in the context of supermarket is hence interesting and in need.

Unfortunately, there are limited studies on customer experiences in in-store environments from an all-inclusive approach (Petermans et al., 2013 in Terblanche, 2018). Most of the retail studies are focusing on examining the various in store experiences such as visual merchandising (Park, Jain, \& Sullivan, 2015); store atmosphere (Hussan \& Ali, 2015); or even compare omni-retailing store atmosphere on purchase intention (Lazaris, Vrechopoulos, Doukidis, \& Fraidaki, 2015). Teblanche's (2018) study examines only repurchase intention; and WoM was consistently left out in the examination of customer loyalty, particularly in the context of supermarkets. It is not clear how in store experiences could affect customer satisfaction and eventually encourage them to share positive WoM. Furthermore, there is only a handful of Malaysian recent retail study focusing on supermarket retail. Considering the tougher and more competitive market outlook, this study will investigate the relationship of in-store experiences (convenience, merchandise value, internal shop environment, interaction with staff, merchandise variety, presence interaction with other customers, and in-shop emotion) and positive WoM with customer satisfaction as mediator in the context of Malaysian supermarkets.

\section{Hypotheses Development}

Koeck and Marshall (2015) discussed the theory of word of mouth (WOM) where people getting and passing information through WoM with their own interpretation based on the concept of "two-step flow of communication" theorised by Lazarsfeld, Berelson and Gaudet (1945). The theory was later evolved into "multi-step flow of communication" where individuals obtained information from various sources and information was exchanged among individuals such as opinion leaders (Robinson, 1976; Weimann, 1982; Burt, 1999, Troldahl \& Van Dam, 1965). Huete-Alcocer (2017) compared the differences between traditional WOM and electronic word of mouth (eWOM), in which traditional WOM was posited to be more credible as consumers tend to believe in what was told to them in person rather than anonymous on the internet. It is often an interpersonal conversation that convey messages in real time which making it less accessible to certain party compared to eWOM where the messages were recorded and given to platforms that can be accessed by any individuals at their convenient.

In consumer studies, Bowen and Chen (2001) and Bettencourt (1997) concluded that customers will spread positive WoM and recommend their preferred store to their peers which eventually improve store's reliability level and reduce customer's perceived risk. They also provide feedbacks on the shortcomings and hoping for improvements. Long-time customers are more likely to spread both WOM compared to new customers as the former had good experience which would make them a reputable source for newcomers (Karjaluoto, Munnukka, \& Kiuru, 2016). Customer experience is defined as "a totally positive, engaging, enduring, and socially fulfilling physical and emotional customer experience across all major levels of one's consumption chain and one that is brought about by a distinct market offering that calls for active interaction between customers and providers" (Mascarenhas, Kesavan, \& Bernacchi, 2006, p. 399). Some posit the importance of interpersonal relationship between employees and customers (Gremler, Gwinner, \& Brown, 2001) to encourage positive WoM behaviour rather than just providing goods or services that are merely satisfied their customers. Others argue that company image can affect the willingness of consumers spreading positive WoM (Ferguson, Paulin, \& Leiriao, 2007); while Casalo', Flavia 'n and Guinal' iu's (2008) study found out that satisfaction is the key determinant of positive WoM. It is rather inconclusive the impacts of consumers' in store vs. out of store experiences/perceptions that 
lead to WoM. Terblanche (2018) hence called for the need to examine the in-store experiences.

\subsection{Convenience}

It is generally agreed that businesses that fulfilled the convenience criteria set by customers will be able to gain more customers (Brown, 1990) because consumers would prefer to spend minimal effort in order to get the desired outcomes. Convenience is significantly related to customer satisfaction and behavioural intentions (Andaleeb \& Basu, 1994; Jiang, Yang, \& Jun, 2013; Seiders et al., 2005). However, researchers and consumers may base on different benchmarks in assessing the convenience aspects of a retail store (Reimers, 2014), making the assessment of convenience inaccurate. Importantly, consumers could shift their definition of convenience based on the nature of retail stores. In-store convenience provided by retailers (e.g., air conditioning, return policy, and payment option) was much valued compared to accessibility or parking spaces in the case of retail store. Shopping enjoyment among consumers increased as their satisfaction against the store convenience increased (Reimers \& Chao, 2014). Access convenience is less important for consumers on choosing the stores as consumers tend to switch stores based on the offers given by retailers (Benoit, Klose, \& Ettinger, 2017). Availability of items are important to them as most customers do not visit several stores to get what they want (Hjelmar, 2011). Therefore, grocery shopping at the supermarkets located close to them becomes their first choice. Still, some consumes are found to visit stores that are located far away from them due to higher satisfaction gained (Jones, Mothersbaugh, \& Beatty, 2003).

Search convenience, transaction convenience, and decision convenience are more applicable as these three aspects are found to enhance customer satisfaction level among consumers in the retail stores and service-based stores (Benoit et al., 2017; Nyuyen, DeWitt, \& Russell-Bennet, 2012). Roy, Shekhar, Lassar, and Chen (2018) concluded that businesses; especially service-based businesses have to factor service convenience into their operation to ensure their customers undergo seamless experience from pre-consumption stage, consumption stage, and post-consumption stage. The seamless experience experienced by consumers is part of the convenience aspect provided by the businesses which will further enhance customer satisfaction. Therefore,

H1: Convenience positively affects customer satisfaction.

\subsection{Merchandise Value}

Merchandise value is a compromise between money spent and benefits offered by supermarket (Sirohi, Mclaughlin, \& Wittink, 1998). It is consumer's overall evaluation of the store's merchandise based on the perceived fit between the overall quality and price of the merchandise (Chaudhuri \& Ligas, 2009). Baker, Parasuraman, Grewal and Voss (2002) suggested that consumer product value perception will be lower when price goes up. They will evaluate the worthiness of products prior making any purchase decisions and they will most likely look around to get the average pricing. Merchandise value had strong impact against customer satisfaction which would manipulate the feeling of customers towards the stores (Sivadas \& Jindal, 2017; Poncin \& Mimoun, 2014). Hanaysha (2018) suggested retailers to convey the store's values to their customers in order to maintain its competitive advantage in the highly competitive marketplace environment. Therefore,

H2: Merchandise value positively affects customer satisfaction.

\subsection{Internal Shop Environment}

Tangible and intangible aspects of the shop environment can be utilised to produce emotional effects to increase the likelihood of consumer purchase (Marques, Cardosa \& Palma, 2013). Consumers tend to react more positively to positive stimuli such as a coherent atmosphere (Mattila \& Wirtz, 2001). Internal shop environment consists of various elements that are visible and invisible (i.e., amenities, fixtures, layout, and product presentation) to the consumers (Terblanche, 2018) and it plays an important role in triggering customer to make their purchase (Hanaysha, 2018; Nair, 2017; Chang, Chen, Hsu, \& Kuo, 2010; Terblanche, 2018). It is also the main factors inducing emotional responses that causing consumers to stay longer in the store, spend more money than he/she expected, and willingness to interact with the store's employees (Donovan \& Rossiter, 1982)

For instance, store layout is found to be important in achieving greater satisfaction among the customers (Mohan, Sivakumaran, \& Sharma, 2012; Marques et al., 2013; Tomazelli, Broilo, Espartel, \& Basso, 2017). Other researchers found stores with more posters regarding social content are able to increase perceived merchandise quality and perceived service quality among customers (Hu \& Jasper, 2006). Therefore,

H3: Internal shop environment positively affects customer satisfaction.

\subsection{Interaction with Staff}

Businesses need to aware of customer emotions in order for the former to be able to provide solutions consumers 
need (Menon \& Dubé, 2000). Customer information obtained through the frontline employees is used to improve their services (Bitner, Booms, \& Mohr, 1994). However, businesses cannot rely fully on that due to variability in service delivery among employees. Good and consistent service provided by the in-store employees is hence critical.

The quality of interpersonal interaction between the customers and employees affects the customer satisfaction level as greater rapport and good employee responsiveness will bring higher customer satisfaction (Bitner et al., 1994; Brown \& Lam, 2008; Marques et al., 2013; Menon \& Dubé, 2000). Tomazelli et al. (2017) stated that customers, especially senior citizens; prefer store personnel assistance rather than having other customers to give them a hand in their shopping activity. In addition, well-mannered and knowledgeable store personnel are crucial in ensuring positive customer emotions that will led to positive customer satisfaction in the long-run (Terblanche, 2018). Therefore,

H4: Interaction with staff positively affects customer satisfaction.

\subsection{Merchandise Variety}

Customers used variety of goods over other aspects as benchmarking tool to measure retailers (Pan \& Zinkhan, 2006). Donovan, Rossiter, Marcoolyn and Nesdale (1994) and Mantrala, Levy, Kahn et al. (2009) in their studies posit that the variety of merchandise offered by the stores will ensure desirable customer satisfaction level as retailers fully understand the customers' preferences and able to fulfil customers' demands. Therefore,

H5: Merchandise variety positively affects customer satisfaction.

\subsection{Presence Interaction with Other Customers}

Pons, Giroux, Mourali and Zins (2016) suggested that customers in the store might be able to experience a pleasing in-store experience for other customers through their actions and gestures (Bonnin \& Goundey, 2012; Borghini et al., 2012). In fact, customers who involve themselves in promoting certain items to other customers will feel more satisfied as they felt that they are being helpful to other customers in the store (Tombs \& McColl-Kennedy, 2003; López-López, Ruiz-de-Maya, \& Warlop, 2014). This is particularly true among senior citizens (Tomazelli et al., 2017). Bracato, Voorhees, and Baker (2012) attributed this to the sense of similarity felt between the customers and the other customers, in which they tend to evaluate others based on their own behaviours. Customer satisfaction will be higher when they feel that they had made a right decision to come into the store that full of people who are similar to themselves. Interestingly, Li, Kim, and Lee (2009) found out that high traffic of crowd in a supermarket will also bring positive impact towards consumers' feeling by treating the crowd as a sense of confirmation on good bargain in the store. Therefore,

H6: Presence interaction with other customers positively affects customer satisfaction.

\subsection{In-Shop Emotion}

Lin and Liang (2011) stated that emotion has gained attention as a central element in understanding service encounters and experiences. Customers experience more positive emotion when they are being treated politely by the employees. In fact, some will most likely mimic the service employee behaviour subconsciously. Walsh, Shiu, Hassan, Michealidou and Beatty (2011) discovered that both arousal and pleasure felt by consumers in the store will increase their satisfaction towards the store.

Several studies had indicated that positive emotion contributed to higher level of satisfaction (Machleit \& Mantel, 2001; Dawson et al., 1990; Oliver, 1999). This is due to the positive emotion induces customer to view the store as live up to their expectations. Therefore,

H7: In-shop emotion positively affects customer satisfaction.

\subsection{Customer Satisfaction}

Customer satisfaction is a universal theory that represents result of the overall affective response after consumption of service (Kim \& Lee, 2011). It was defined as the degree of overall pleasure or contentment felt by customers, resulting from the ability to fulfil customer's desires, expectations and needs in relation to the services (Hellier et al., 2003). The state of emotion will greatly affect the shopping experience which eventually leads to different levels of satisfaction with the retail environment (Jiunn-Ger et al., 2009).

Consumers tend to avoid the stores that do not live up to their expectations (Esbjerg, Jensen, Bech-Larsen, Barcellos, Boztug, \& Grunert, 2012). Customer satisfaction level is positively linked with the benefits of the store services (Chang et al., 2010). Consumers talk about their post purchase experiences with other people and satisfied customers are more likely to spread positive WoM (Chang et al., 2010; Ranaweera \& Prabhu, 2003). 
Individuals who had good prior experience with a brand will also tend to promote the brand to their peers (Karjaluoto et al., 2016). Therefore,

H8: There is a positive relationship between customer satisfaction and positive WoM.

Compared to new customers, long-time customers are more likely to spread both WOM and eWOM as they had good experience which makes them a reputable source for newcomers for information regarding brands, goods or services (Karjaluoto, et al., 2016). Their in-store experiences will determine the satisfaction level and eventually lead to willingness to share positive WoM with others. For instance, customer satisfaction level is positively linked with the benefits of the services provided by the stores (Chang et al., 2010). However, Chang et al. failed to find significant relationships between product quality and convenience against customer satisfaction. The inconsistent findings lead the assumption of the mediation role play by satisfaction in the relationships between in store experiences and positive WoM. Therefore,

H9: Customer satisfaction mediates the relationship between (a). convenience; (b). merchandise value, (c). internal shop environment; (d). interaction with staff; (e). merchandise variety; (f). presence interaction with other customers; (g). in-shop emotion and positive WoM.

\section{Methodology}

\subsection{Research Framework}

This study expanded Terblanche's (2018) framework by adding two additional variables, namely convenience (Seiders et al., 2005) and positive WoM (Bridson, Evans, \& Hickman, 2008). Convenience was added due to its importance in enhancing customer satisfaction (Benoit et al., 2017; Nguyen et al., 2012). WoM is a powerful tool that businesses cannot underestimate as it can help businesses to retain existing customers while gaining new customers at the same time. This study provides a comprehensive examination of the relationships between in store shopping experience variables (convenience, merchandise value, internal shop environment, interaction with staff, merchandise variety, presence interaction with other customers and in-shop emotion.

The measurement items for convenience were adapted from Seiders et al. (2005), meanwhile the measurement items for merchandise value were adapted from Chaudhuri and Ligas (2009) and Baker, Grewal, and Parasuraman (1994). The measurement items for internal shop environment were adapted from Marques, et al. (2013). The measurement items for interaction with staff and presence interaction with other customers were adapted from Marques et al. (2013) and Terblanche (2018). The measurement items for merchandise variety were adapted from Terblanche (2018). The measurement items for in-shop emotion were adapted from Terblanche (2018) and Mohan et al. (2012). The measurement items for customer satisfaction were adapted from Kim and Lee (2009) and Ruiz, Gremler, Washburn, and Carrión (2008). Finally, the measurement items for convenience were adapted from Bridson et al. (2008).

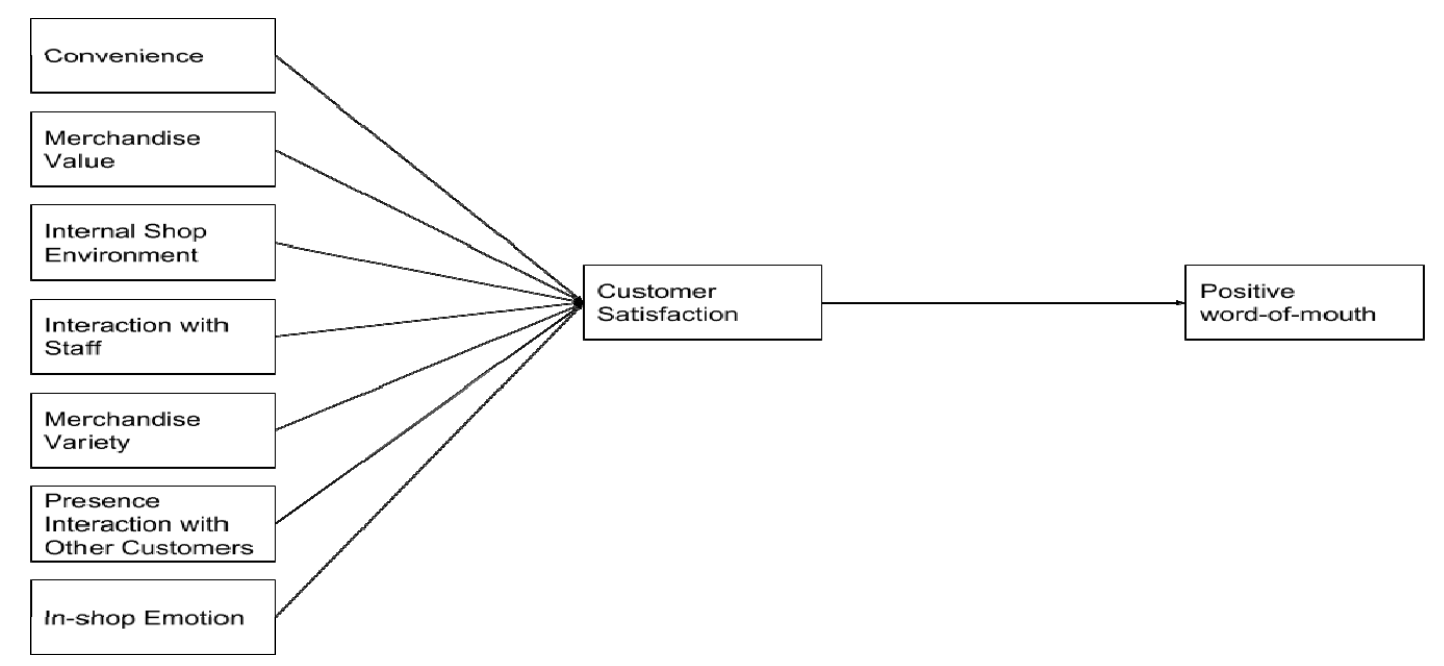

Figure 1. Conceptual framework

Source: Adapted from Terblanche (2018); Seiders et al. (2005); and Bridson et al. (2008). 


\subsection{Sampling Method and Sample Size}

Due to absence of sampling frame of all supermarket shoppers, mall intercept was adopted and these respondents were pre-screened for the buying frequency. Only supermarket customers who visited supermarkets of their choice at least once a week for grocery shopping were chosen. Judgment sampling was hence applied as the choices of "subjects are those most advantageously placed or the best position to provide the information required" (Sekaran \& Bougie, 2009, p. 277). Primary data collected through questionnaires was analysed by using two programs: Statistical Package for the Social Sciences (SPSS) version 24 and Smart Partial Least Square (Smart PLS) version 3.2.7. This paper also adopted quantitative research as it is the most commonly method in marketing studies (Hansen \& Grimmer). Reliability and validity are used to "defend generalizations and specify the extent to which certainty has been achieved" (Hansen \& Grimmer, p. 59) and has "satisfactorily covered all the relevant angles in a quantitative project: theory, method, results, and discussion can fit into a tight word limit" (Hansen \& Grimmer, p. 68).

G*Power analysis was performed to identify the minimum required sample size with the effect size of 0.15 with significant level at 95 per cent for seven predictors as suggested by Cohen (1988). The minimum sample size suggested by a priori test was 153 sets of data. Convenience sampling method was adopted where printed questionnaires were distributed to individuals at various supermarkets and locations using mall intercepts. Electronic questionnaires were also distributed through Facebook and WhatsApp. A total of 213 questionnaires were collected which comprised of 122 sets of printed questionnaires and 91 sets of electronic questionnaires. Only 155 sets of answers were regarded as valid responses (response rate of $72.28 \%$ ).

\section{Findings}

A majority of the respondents were single (53.5\%) Chinese (42.6\%) female (51.6\%) aged between 26-32 years old $(35.5 \%)$ and hold a bachelor degree (32.9\%). $61.9 \%$ of them worked as private sector employees and earned between RM2000-RM2999 per month (31\%). 63.9\% of them visit the supermarkets 1 to 2 times a week while $30.3 \%$ of them visited the supermarket 3 to 4 times a week (30.3\%). Most of them spent less than RM100 per trip (51.6\%) while $25.2 \%$ of them spent RM120 and above. More than half of the respondents $(62.6 \%)$ bought a combination of food and non-food items when they visit the supermarket while $33.5 \%$ of the respondents purchased only food items.

Common method variance (CMV) was tested by executing Harman's single factor test. Podsakoff, Mackenzie, Lee, and Podsakoff (2003) stated that CMV does not affect the data if the total variance for a single component is less than $50 \%$. The test generated a single component which explained $21.31 \%$ of variance, indicated that CMV is of no concern in this study.

Table 1 shows the mean and standard deviation for all variables, namely convenience, merchandise value, internal shop environment, interaction with staff, merchandise variety, presence interaction with other customers, in-shop emotion, customer satisfaction and positive word-of-mouth. The mean scores for all variables were slightly above 3 (neutral) indicated rather positive responses. All variables have standard deviations less than 1 except internal shop environment, interaction with staff and presence interaction with other customers.

Table 1. Descriptive analysis for variable

\begin{tabular}{lll}
\hline Variables & Mean & Standard Deviation \\
\hline Convenience & 3.981 & 0.981 \\
Merchandise Value & 3.754 & 0.898 \\
Internal Shop Environment & 3.549 & 1.022 \\
Interaction with Staff & 3.326 & 1.044 \\
Merchandise Variety & 3.886 & 0.977 \\
Presence Interaction with Other Customers & 3.071 & 1.096 \\
In-shop Emotion & 3.822 & 0.941 \\
Customer Satisfaction & 3.790 & 0.812 \\
Positive Word-of-Mouth & 3.791 & 0.908 \\
\hline
\end{tabular}

\subsection{Convergent and Discriminant Validity}

Hair, Black, and Babin (2006) stated that convergent validity is the degree to which a measure relates positively with alternate measures of the same construct. MERVALUE5, ISENV6, ISENV7, ISENV8, INTSTAFF1, INTSTAFF3, INTCUST1 were remove from the model due to low factor loading values. Hair, Ringle, and 
Sarstedt (2011) stated that the recommended value for CR is 0.7 and above, and the recommended value of AVE (Chin, 1998) and factor loading had to be more than 0.5. Refer to Table 2, all outer loadings, AVE, CR indicated acceptable convergent validity.

Table 2. Internal composite reliability and convergent validity

\begin{tabular}{|c|c|c|c|c|c|}
\hline Construct & Measurement Item & Loading & AVE & $\mathrm{CR}$ & Cronbach's Alpha \\
\hline \multirow[t]{5}{*}{ Convenience } & CON1 & 0.764 & 0.534 & 0.851 & 0.787 \\
\hline & CON2 & 0.753 & & & \\
\hline & CON3 & 0.709 & & & \\
\hline & CON4 & 0.748 & & & \\
\hline & CON5 & 0.677 & & & \\
\hline \multirow[t]{4}{*}{ Merchandise Value } & MERVALUE1 & 0.745 & 0.555 & 0.831 & 0.726 \\
\hline & MERVALUE2 & 0.814 & & & \\
\hline & MERVALUE3 & 0.800 & & & \\
\hline & MERVALUE4 & 0.603 & & & \\
\hline \multirow[t]{5}{*}{ Internal Shop Environment } & ISENV1 & 0.748 & 0.507 & 0.834 & 0.760 \\
\hline & ISENV2 & 0.843 & & & \\
\hline & ISENV3 & 0.762 & & & \\
\hline & ISENV4 & 0.630 & & & \\
\hline & ISENV5 & 0.540 & & & \\
\hline \multirow[t]{5}{*}{ Interaction with Staffs } & INTSTAFF2 & 0.555 & 0.553 & 0.849 & 0.773 \\
\hline & INTSTAFF4 & 0.684 & & & \\
\hline & INTSTAFF5 & 0.786 & & & \\
\hline & INTSTAFF6 & 0.791 & & & \\
\hline & INTSTAFF7 & 0.804 & & & \\
\hline \multirow[t]{4}{*}{ Merchandise Variety } & MERVARIETY1 & 0.761 & 0.661 & 0.886 & 0.827 \\
\hline & MERVARIETY2 & 0.884 & & & \\
\hline & MERVARIETY3 & 0.851 & & & \\
\hline & MERVARIETY4 & 0.747 & & & \\
\hline Presence Interaction with & INTCUST2 & 0.608 & 0.564 & 0.856 & 0.809 \\
\hline \multirow{4}{*}{ Other Customers } & INTCUST3 & 0.803 & & & \\
\hline & INTCUST4 & 0.790 & & & \\
\hline & INTCUST5 & 0.838 & & & \\
\hline & INTCUST6 & 0.694 & & & \\
\hline \multirow[t]{5}{*}{ In-shop Emotion } & ISEMOTION1 & 0.705 & 0.684 & 0.915 & 0.883 \\
\hline & ISEMOTION2 & 0.827 & & & \\
\hline & ISEMOTION3 & 0.865 & & & \\
\hline & ISEMOTION4 & 0.876 & & & \\
\hline & ISEMOTION5 & 0.851 & & & \\
\hline \multirow[t]{4}{*}{ Customer Satisfaction } & CUSSAT1 & 0.775 & 0.667 & 0.889 & 0.833 \\
\hline & CUSSAT2 & 0.796 & & & \\
\hline & CUSSAT3 & 0.827 & & & \\
\hline & CUSSAT4 & 0.854 & & & \\
\hline \multirow[t]{5}{*}{ Positive Word-of-Mouth } & PWOM1 & 0.740 & 0.637 & 0.898 & 0.859 \\
\hline & PWOM2 & 0.815 & & & \\
\hline & PWOM3 & 0.826 & & & \\
\hline & PWOM4 & 0.804 & & & \\
\hline & PWOM5 & 0.803 & & & \\
\hline
\end{tabular}

Note: $\mathrm{AVE}=$ Average Variance Extracted, $\mathrm{CR}=$ Composite Reliability.

Discriminant validity is examined by examining Fornell and Larcker's criterion and heterotrait-monotrait ratio of correlations (HTMT) (Hair et al., 2011). Table 3 showed that discriminant validity existed between all the constructs as the square roots of AVEs on the diagonal were greater than the values of inter-constructs on the same columns and rows. 
Table 3. Fornell-larcker's criterion

\begin{tabular}{|c|c|c|c|c|c|c|c|c|c|}
\hline Constructs & $\mathrm{C}$ & $\mathrm{CS}$ & ISEMO & IWS & ISENV & MVAL & MVAR & PWOM & PIWOC \\
\hline $\mathrm{C}$ & 0.731 & & & & & & & & \\
\hline $\mathrm{CS}$ & 0.451 & & & & & & & & \\
\hline ISEMO & 0.305 & 0.613 & 0.827 & & & & & & \\
\hline IWS & 0.249 & 0.395 & 0.344 & 0.730 & & & & & \\
\hline ISENV & 0.271 & 0.293 & 0.358 & 0.242 & 0.712 & & & & \\
\hline MVAL & 0.296 & 0.293 & 0.245 & 0.328 & 0.144 & 0.745 & & & \\
\hline MVAR & 0.266 & 0.387 & 0.384 & 0.251 & 0.217 & 0.104 & 0.813 & & \\
\hline PWOM & 0.293 & 0.605 & 0.445 & 0.336 & 0.254 & 0.366 & 0.345 & 0.798 & \\
\hline PIWOC & 0.213 & 0.318 & 0.377 & 0.239 & 0.250 & 0.114 & 0.109 & 0.270 & 0.751 \\
\hline
\end{tabular}

The values of HTMT criterion were ranging from 0.0162 to 0.492 , which were lower than the threshold value of HTMT.85 (Kline, 2011) and HTMT.90 (Gold, Malhotra, \& Segar, 2001). Both Fornell and Larcker's Criterion and HTMT results indicated acceptable discriminant validity.

Table 4. HTMT Criterion

\begin{tabular}{|c|c|c|c|c|c|c|c|c|}
\hline & $\mathrm{C}$ & ISEMO & IWS & ISENV & MVAL & MVAR & PWOM & PIWOC \\
\hline \multicolumn{9}{|l|}{$\mathrm{C}$} \\
\hline ISEMO & 0.333 & & & & & & & \\
\hline IWS & 0.305 & 0.416 & & & & & & \\
\hline ISENV & 0.319 & 0.402 & 0.334 & & & & & \\
\hline MVAL & 0.366 & 0.301 & 0.443 & 0.267 & & & & \\
\hline MVAR & 0.309 & 0.451 & 0.326 & 0.298 & 0.220 & & & \\
\hline PWOM & 0.319 & 0.492 & 0.413 & 0.323 & 0.462 & 0.409 & & \\
\hline PIWOC & 0.242 & 0.426 & 0.291 & 0.293 & 0.164 & 0.162 & 0.302 & \\
\hline
\end{tabular}

Note: $\mathrm{C}=$ Convenience, $\mathrm{CS}=$ Customer Satisfaction, ISEMO = In-shop Emotion, IWS = Interaction with Staff, ISEVN = Internal Shop Environment, MVAL $=$ Merchandise Value, MVAR $=$ Merchandise Variety, PWOM $=$ Positive Word-of-mouth, PIWOC $=$ Presence Interaction with Other Customers.

Kock and Lynn (2012) stated that lateral collinearity issue might cause mislead findings in a hidden way as it can hide strong causal effect in the model. The examination of the VIF values showed the inner VIF value of all predictor constructs were less than 5, indicating that lateral multicollinearity is not a concern in this study (Hair et al., 2011).

\subsection{Hypothesis Testing}

Refer to Table 5, H1, H7 and H8 were supported while H2, H3, H4, H5 and H6 were not supported. Out of the seven instore experience examined, only convenience $(\beta=0.228, \mathrm{p}<0.001)$ and in-shop emotion $(\beta=0.412, \mathrm{p}<$ 0 ) were positively related to customer satisfaction. Meanwhile, merchandise value, internal shop environment, interaction with staff, merchandise variety, and presence interaction with other customers were not significantly related to customer satisfaction. Customer satisfaction also positively related to positive $\operatorname{WoM}(\beta=0.605, \mathrm{p}<0)$.

Hair, Sarstedt, Hopkins and Kepperwieser (2014) also suggested that $\mathrm{R}^{2}$ value should be examined and described with 0.75 being substantial, 0.50 being moderate, and 0.25 being weak. The $\mathrm{R}^{2}$ value was 0.492 which regarded as moderate.

Sullivan and Fein (2012) posited that it is essential to report the substantive significance (effect size) and statistical significance (p-value). Cohen (1988) stated three values to represent small, medium, and large effect size; namely $0.02,0.15$, and 0.35 . According to Table 5 , customer satisfaction had the largest effect on positive WoM $\left(f^{2}=0.577\right)$, followed by in-shop emotion had medium effect on customer satisfaction $\left(f^{2}=0.219\right)$; while convenience $\left(\mathrm{f}^{2}=0.082\right)$ had a small effect on customer satisfaction.

On top of that, Hair et al. (2014) and Fornell and Cha (1994) concluded the model has predictive relevance for some endogenous construct if its $\mathrm{Q}^{2}$ value is greater than 0 . The result of the blindfolding procedure indicated customer satisfaction $\left(Q^{2}=0.291\right)$ and positive word-of-mouth $\left(Q^{2}=0.194\right)$ were having $Q^{2}$ value that is greater 
than 0 , showing that the model had sufficient predictive relevance.

Table 5. Results of hypotheses testing

\begin{tabular}{|c|c|c|c|c|c|c|c|c|c|c|}
\hline Hypothesis & Relationship & $\begin{array}{l}\text { Std. } \\
\text { Beta }\end{array}$ & $\begin{array}{l}\text { Std. } \\
\text { Error }\end{array}$ & t-value & p-value & Decision & $\mathrm{R}^{2}$ & $\mathrm{f}^{2}$ & $\begin{array}{l}\text { Effect } \\
\text { Size }\end{array}$ & $\mathrm{Q}^{2}$ \\
\hline $\mathrm{H} 1$ & $\begin{array}{l}\text { Convenience -> Customer } \\
\text { Satisfaction }\end{array}$ & 0.228 & 0.066 & $3.442 * *$ & $0.001 * *$ & Supported & 0.492 & 0.082 & Small & 0.291 \\
\hline $\mathrm{H} 2$ & $\begin{array}{l}\text { Merchandise Value -> } \\
\text { Customer Satisfaction }\end{array}$ & 0.062 & 0.066 & 0.942 & 0.347 & $\begin{array}{l}\text { Not } \\
\text { Supported }\end{array}$ & & 0.006 & Small & \\
\hline H3 & $\begin{array}{l}\text { Internal Shop Environment -> } \\
\text { Customer Satisfaction }\end{array}$ & 0.001 & 0.071 & 0.015 & 0.988 & $\begin{array}{l}\text { Not } \\
\text { Supported }\end{array}$ & & 0 & Small & \\
\hline $\mathrm{H} 4$ & $\begin{array}{l}\text { Interaction with Staff -> } \\
\text { Customer Satisfaction }\end{array}$ & 0.131 & 0.072 & $1.817 * *$ & 0.070 & $\begin{array}{l}\text { Not } \\
\text { supported }\end{array}$ & & 0.026 & Small & \\
\hline H5 & $\begin{array}{l}\text { Merchandise Variety -> } \\
\text { Customer Satisfaction }\end{array}$ & 0.121 & 0.080 & 1.514 & 0.131 & $\begin{array}{l}\text { Not } \\
\text { Supported }\end{array}$ & & 0.023 & Small & \\
\hline H6 & $\begin{array}{l}\text { Presence Interaction with Other } \\
\text { Customers -> Customer } \\
\text { Satisfaction }\end{array}$ & 0.062 & 0.071 & 0.881 & 0.379 & $\begin{array}{l}\text { Not } \\
\text { Supported }\end{array}$ & & 0.006 & Small & \\
\hline $\mathrm{H} 7$ & $\begin{array}{l}\text { In-shop Emotion -> Customer } \\
\text { Satisfaction }\end{array}$ & 0.412 & 0.076 & $5.454^{* *}$ & $0.001 * *$ & Supported & & 0.219 & Medium & \\
\hline H8 & $\begin{array}{l}\text { Customer Satisfaction -> } \\
\text { Positive Word-of-Mouth }\end{array}$ & 0.605 & 0.052 & $11.557 * *$ & $0.001 * *$ & Supported & & 0.577 & Large & 0.194 \\
\hline
\end{tabular}

Note: One tailed test, $* *$ t-value $>2.33(\mathrm{p}<0.01)$; ${ }^{*}$-value $>1.65(\mathrm{p}<0.05)$.

\subsection{Mediation Analysis}

Table 6 showed the findings of mediation analysis on this study where customer satisfaction mediated four out of seven relationships. In this study, mediating effect is achieved if there is no zero between upper limit (UL) value and lower limit (LL) value (Ramayah, 2014). The four significant relationships were convenience and positive WoM $(\beta=0.138, p<0.001)$, interaction with staff and positive WoM $(\beta=0.079, \mathrm{p}<0.074)$, merchandise variety and positive $\operatorname{WoM}(\beta=0.073, \mathrm{p}<0.159)$, and in-store emotion and positive $\operatorname{WoM}(\beta=0.249, \mathrm{p}<0)$.

Table 6. Mediation analysis

\begin{tabular}{|c|c|c|c|c|c|c|c|c|}
\hline Hypothesis & Relationship & $\begin{array}{l}\text { Indirect } \\
\text { Effect. Beta }\end{array}$ & $\begin{array}{l}\text { Std. } \\
\text { Error }\end{array}$ & t-value & p-values & LL & UL & Remark \\
\hline H9(a) & $\begin{array}{l}\text { Convenience -> Customer } \\
\text { Satisfaction -> Positive } \\
\text { Word-of-Mouth }\end{array}$ & 0.138 & 0.042 & $3.271 * *$ & $0.001 *$ & 0.070 & 0.206 & Mediation \\
\hline H9(b) & $\begin{array}{l}\text { Merchandise Value -> Customer } \\
\text { Satisfaction -> Positive } \\
\text { Word-of-Mouth }\end{array}$ & 0.037 & 0.041 & 0.911 & 0.363 & -0.027 & 0.110 & No Mediation \\
\hline $\mathrm{H} 9(\mathrm{c})$ & $\begin{array}{l}\text { Internal Shop Environment -> } \\
\text { Customer Satisfaction -> Positive } \\
\text { Word-of-Mouth }\end{array}$ & 0.001 & 0.044 & 0.014 & 0.988 & -0.065 & 0.080 & No Mediation \\
\hline H9(d) & $\begin{array}{l}\text { Interaction with Staff -> Customer } \\
\text { Satisfaction -> Positive } \\
\text { Word-of-Mouth }\end{array}$ & 0.079 & 0.044 & 1.790 & 0.074 & 0.007 & 0.152 & No Mediation \\
\hline H9(e) & $\begin{array}{l}\text { Merchandise Variety -> Customer } \\
\text { Satisfaction -> Positive } \\
\text { Word-of-Mouth }\end{array}$ & 0.073 & 0.052 & 1.411 & 0.159 & 0.002 & 0.172 & No Mediation \\
\hline H9(f) & $\begin{array}{l}\text { Presence Interaction with Other } \\
\text { Customers -> Customer Satisfaction } \\
\text {-> Positive Word-of-Mouth }\end{array}$ & 0.038 & 0.044 & 0.859 & 0.391 & -0.026 & 0.123 & No Mediation \\
\hline $\mathrm{H} 9(\mathrm{~g})$ & $\begin{array}{l}\text { In-shop Emotion -> Customer } \\
\text { Satisfaction -> Positive } \\
\text { Word-of-Mouth }\end{array}$ & 0.249 & 0.050 & $4.957 * *$ & $0.001 * *$ & 0.159 & 0.321 & Mediation \\
\hline
\end{tabular}

Note: Two tailed test, ${ }^{* *}$ t-value $>2.58(\mathrm{p}<0.01) ; *$ t-value $>1.96(\mathrm{p}<0.0)$. 


\section{Discussion and Conclusion}

The study was conducted to investigate the effects of in-store experience towards customer satisfactions as well as the effect of customer satisfaction on positive WoM in the context of Malaysian supermarket. Only two out of the seven exogenous variables examined was significant, namely convenience and in-shop emotion. Merchandise value, internal shop environment, interaction with staff, merchandise variety and presence interaction with other customers do not have significant relationships with customer satisfaction. These findings are consistent with previous studies that convenience and in-shop emotion are the main predictors for customer satisfaction (Andaleeb \& Basu, 1994; Reimers \& Chao, 2014; Walsh et al., 2011; Machleit \& Mantel, 2001; Dawson et al., 1990; Oliver, 1993).

The significant relationship between convenience and customer satisfaction is consistent with Hjelmar's (2011) and Jones et al.'s (2003) studies. Consumers prefer to spend minimal effort to get the desired outcomes in the retail stores, making convenience an important contributor to satisfaction, consistent with Andaleeb and Basu (1994); Jiang et al. (2013), and Seider et al. (2015). It is interesting to find insignificant relationship between merchandise value and customer satisfaction which is not in line with the previous findings by Sivadas and Jindal (2017) and Poncin and Mimoun (2014). One of the possible explanations could be due to the lack of differentiation in term of merchandise quality sold in one supermarket compared to the others. Stiff price competition among the supermarkets retailers is found to close the merchandise price gaps. Consumers perceive less price differences among supermarket retailers making merchandise value less significant. In addition, most of the grocery products sold in the supermarkets are either national brands (for packaged food) or fresh produced (e.g., vegetables or poultry). These products are either sold at a tight margin or as loss leaders (e.g., poultry) to attract higher patronage, which eventually lead to small prices differences among supermarket retailers.

The relationship between internal shop environment and customer satisfaction was also insignificant. This finding contradicted several studies suggested that businesses should take store environmental aspect into their managerial procedure in order to have more satisfied customers, having them to stay longer in the store, and spend more than what they had planned which will generate more revenue for the businesses in long run. (Donovan \& Rossiter, 1982; Mohan et al., 2012; Marques et al., 2013; Tomazelli et al., 2017; Hanaysha, 2018; Nair, 2017; Chang et al., 2010). The result of present study implied that the arrangement of products and layout of the supermarket will not affect customer satisfaction. This could be attributed to the reason that consumers frequently visit neighbourhood supermarkets to shop for their groceries. The store environment would not affect their satisfaction as convenience played a larger role.

The relationship between interaction with staff and customer satisfaction was also insignificant. This could be attributed to the fact that consumers who visited supermarkets required minimal assistance from the employees. The respondents were mainly adults aged between 26 to 35 years old that are able to handle most of their shopping tasks such as checking on price tags, product category, and product information. The non-negotiable pricing policy of the supermarkets minimizes the need for interaction with staff. Most of the consumers who visited the neighbourhood supermarkets are frequent customers who are familiar with the supermarket's layout and floorplan; thus, making interaction with the supermarket's employees less significant.

The relationship between merchandise variety and customer satisfaction was insignificant. Variation of merchandise available in the supermarket did not affect their satisfaction level. This could be attributed to the reason that consumers might have their preferred products or brands name that available at the supermarket they frequently visited. They only buy what they need and what they normally use for grocery items. Merchandise variety hence play less significant role. Brand name and packaging would have less significant impacts on grocery items include staple foods (i.e., flour, sugar, salt, rice, meat, and vegetable).

Similar to interaction with staff, the relationship between presence interaction with other customers and customer satisfaction was insignificant. Most of respondents visited supermarket 1-2 times a week. Some of them could be working adults who dropped by at the neighbourhood supermarkets located along the drive back from work. Convenience is their priority and the limited time spent in the supermarkets makes interaction with other customers less significant. In addition, the grocery products are mostly daily consumed products which high familiarity minimizes the needs to ask others' opinions. This contradicted the studies by Tombs and McColl-Kennedy (2013) and López-López et al., (2014). Furthermore, Cox, Cox, and Anderson (2005) discovered that some customers do not like to interact with other customers when they are doing their shopping. Instead, they enjoy looking for bargains and window shopping, which could be attributed to their preference to hunt for good bargain and are afraid that other customers might have taken the offers.

The significant relationship between in-shop emotion and customer satisfaction indicated that the emotions 
experienced by respondents while they are in the supermarket could affect satisfaction, consistent with Jiunn-Ger et al. (2009). For instance, supermarket is said to fulfil their sense of curiosity toward the goods sold in the store by creating exciting, pleasant and happy moods. They also feel enthusiastic while shopping. Finally, the significant relationship between customer satisfaction and positive WoM showed that one's satisfaction on products and services can affect their decision in giving positive or negative WoM. Satisfied customers were tent more likely to spread positive WoM and return to the store (Chang et al., 2014; Casalo et al., 2008). Most of the respondents were willing to let people know about their pleasant encounters at the supermarket of their choice and recommend the supermarket to their peers. Even though interaction with staff and merchandise variety did not show significant relationship relationships, customer satisfaction was proven to be a valid mediator for the relationships between these two variables and positive WoM. Customer satisfaction also plays important roles in the other two relationships, namely convenience and in store emotions with positive WoM.

This study expanded the supermarket research by examining the relationships between in-store experiences, satisfaction and positive WoM. The findings of the study which rather contradicted the previous studies indicated that retail study could be highly differentiated by demographic, geographic and culture influences. Merchandise value, internal shop environment, interaction with staff, merchandise variety, and presence interaction with other customers were found not to having positive relationships with customer satisfaction which contradicted other studies (Terblanche, 2018; Sivadas \& Jindal, 2017; López-López et al., 2014; Poncin \& Mimoun, 2014; Marques et al., 2013; Tomazelli et al., 2012; Borghini et al., 2012; Mohan et al., 2012; Brown \& Lam, 2008; Menon \& Dubé., 2000; Bitner et al., 1994; Donovan \& Rossiter, 1982). It might be attributed to the nature of grocery retailing, particularly supermarket where consumers are engaging in self-service shopping with less assistance needed. In addition, product display, store layout, and merchandise assortments are mostly consistent across different supermarkets making these variables less significant. The findings also supported the strong relationship between satisfaction and positive WoM and extended the significance of WoM in grocery retail studies, particularly in the context of supermarket. In other words, not only re-patronage or revisit the same supermarket, satisfied supermarket customers are also willing to involve in spreading positive WoM to their friends, peers and relatives. They could become opinion leaders championing the benefits of patronising a particular supermarket.

The findings of the results could be extended to retail markets which are similar to Malaysian context, particularly among the developing nation, where local retail markets are fragmented, at the same time facing stiff global and omni-channel competitions. Supermarkets owners should take actions in improving customer satisfaction of both existing and new customers that visiting their stores as it is the most effective method in getting positive WoM. Firstly, supermarkets should know the segment of customers that they have as this will allow the management to understand how the customers feel and think about the store. The segmentation can be done in the form of store location as consumers tend to visit the nearest supermarkets or stores located from their workplace and/or home and highlight different type of products to the customers. For example, supermarkets located at central business districts could emphasise on convenience packaged food or ready to eat food. Ready to eat take home food could be another potential product for consumers who value convenience and affected by emotion and mood. Convenience in term of payment system as well as air conditioning and return policy could be critical for supermarkets. Supermarkets could look into the opportunity of grocery delivery where customers can order their grocery, and have it delivered to their doorstep; or purchase it in the store and have it delivered on a later date.

Even though merchandise variety is not important, supermarkets still need to have sufficient supply of staple goods in major brand names. This is due to these major brand names had spent tons of money in selling their brands and products to the consumers, thus making supermarket's role as a middleman between marketers and consumers. Nonetheless, Aghazadeh (2005) suggested that supermarkets should place high-impulse and high-margin items that customers do not plan to purchase at the checkout counter to serve as a reminder to customers or create a mood which triggers buying intention to increase cross-selling in the store. Breath mints, gift cards, batteries, drinks, stationeries, and travel size toiletries are some of the examples of high-impulse and high-margin items that can be found at supermarkets.

Future research could increase the sample size to enhance representativeness of the sample. Future research could investigate other attributes of behavioural and attitudinal loyalty in order to further explore the concept of customer loyalty in various applications as well compare different retail formats to include convenience store, minimum and hypermarkets. 


\section{Acknowledgments}

This work is supported by the Universiti Malaysia Sabah, under the SBK grant (SBK0360-2017).

\section{References}

Aghazadeh, S. M. (2005). Layout Strategies for Retail Operations: A Case Study. Management Research News, 28(10), 31-46. https://doi.org/10.1108/01409170510785002

Andaleeb, S. S., \& Basu, A. K. (1994). Technical complexity and consumer knowledge as moderators of service quality evaluation in the automobile service industry. Journal of Retailing, 70(4), 367-381. https://doi.org/10.1016/0022-4359(94)90005-1

Baker, J., Grewal, D., \& Parasuraman, A. (1994). The influence of store environment on quality inferences and store image. Journal of the Academy of Marketing Science, 22(4), 328-339. https://doi.org/10.1177/0092070394224002

Baker, J., Parasuraman, A., Grewal, D., \& Voss, G. B. (2002). The Influence of Multiple Store Environment Cues on Perceived Merchandise Value and Patronage Intentions. Journal of Marketing, 66, 120-141. https://doi.org/10.1509/jmkg.66.2.120.18470

Benoit, S., Klose, S., \& Ettinger, A. (2017). Linking service convenience to satisfaction: dimensions and key moderators. Journal of Services Marketing, 31(6), 527-538. https://doi.org/10.1108/JSM-10-2016-0353

Bettencourt, L. A. (1997). Customer Voluntary Performance: Customers as Partners in Service -Delivery. Journal of Retailing, 73(3), 383-406. https://doi.org/10.1016/S0022-4359(97)90024-5

Bitner, M. J., Booms, B. H., \& Mohr, L. A. (1994). Critical Service Encounters: The Employee's Viewpoint. Journal of Marketing, 58(4), 95-106. https://doi.org/10.1177/002224299405800408

Bonnin, G. L., \& Goudey, A. (2012). The kinetic quality of store design: An Exploration of its influence on shopping experience. Journal of Retailing and Consumer Services, 19, 637-643. https://doi.org/10.1016/j.jretconser.2012.08.006

Borghini, S., MacLaran, P., Bonnin, G., \& Cova, V. (2012). The ecology of the market-place experience: from consumers' imaginary to design implications. In L. Peñaloza, N. Toulouse, \& L. M. Visconti (Eds.), Marketing Management: A Cultural Perspective. New York: Routledge.

Bowen, J. T., \& Chen, S. L. (2001). The relationship between customer loyalty and customer satisfaction. International Journal of Contemporary Hospitality Management, 13(5), $213-217$. https://doi.org/10.1108/09596110110395893

Bridson, K., Evans, J., \& Hickman, M. (2008). Assessing the relationship between loyalty program attributes, store satisfaction and store loyalty. Journal of Retailing and Consumer Services, 15, 364-374. https://doi.org/10.1016/j.jretconser.2007.08.004

Brocato, E. D., Voorhees, C. M., \& Baker, J. (2012). Understanding the Influence of Cues from Other Customers in the Service Experience: A Scale Development and Validation. Journal of Retailing, 88(3), 384-398. https://doi.org/10.1016/j.jretai.2012.01.006

Brown, L. G. (1990). Convenience in Services Marketing. Journal of Services Marketing, 4(1), 53-59. https://doi.org/10.1108/EUM0000000002505

Brown, S. P., \& Lam, S. K. (2008). A Meta-Analysis of Relationships Linking Employee Satisfaction to Customer Responses. Journal of Retailing, 84(3), 243-255. https://doi.org/10.1016/j.jretai.2008.06.001

Burt, R. (1999). The Social Capital of Opinion Leaders. The ANNALS of the American Academy of Political and Social Science, 566(1), 37-54. https://doi.org/10.1177/000271629956600104

Casalo', L. V., Flavia' n, C., \& Guinal' 1u, M. (2008). The role of satisfaction and website usability in developing customer loyalty and positive word-of-mouth in the e-banking services. The International Journal of Bank Marketing, 26(6), 399-417. https://doi.org/10.1108/02652320810902433

Chang, K.C., Chen, M.C., Hsu, C.L., \& Kuo, N.T. (2010). The effect of service convenience on post-purchasing behaviours. Industrial Management \& Data Systems, 110(9), 1420-1443. https://doi.org/10.1108/02635571011087464

Chaudhuri, A., \& Ligas, M. (2009). Consequences of Value in Retail Markets. Journal of Retailing, 85(3), 406-419. https://doi.org/10.1016/j.jretai.2009.05.006 
Chin, W. W. (1998). The partial least squares approach to structural equation modeling. Modern Methods for Business Research, 295(2), 295-336.

Cohen, J. (2013). Statistical Power Analysis for the Behavioural Science (2nd ed.). Hillsdale, NJ: Lawrence Erlbaum Associates. https://doi.org/10.4324/9780203771587

Costello, A. B., \& Osbome, J. W. (2005). Best Practices in Exploratory Factor Analysis: Four Recommendations for Getting the Most from Your Analysis. Practical Assessment, Research \& Education, 10(1-9). https://doi.org/10.1.1.110.9154

Cox, A. D., Cox, D., \& Anderson, R. D. (2005). Reassessing the pleasures of store shopping. Journal of Business Research, 58, 250-259. https://doi.org/10.1016/S0148-2963(03)00160-7

Dawson, S., Bloch, P., \& Ridgway, N. (1990). Shopping motives, emotional states, and retail outcomes. Journal of Retailing, 66(4), 408-427.

Dick, A. S., \& Basu, K. (1994). Customer Loyalty: Toward an Integrated Conceptual Framework. Journal of the Academy of Marketing Science, 22(2), 99-113. https://doi.org/10.1177/0092070394222001

Donovan, R. J., \& Rossiter, J. R. (1982). Store atmosphere: an experimental psychology approach. Journal of Retailing, 58(2), 34-57.

Donovan, R. J., Rossiter, J. R., Marcoolyn, G., \& Nesdale, A. (1994). Store Atmosphere and Purchasing Behaviour. Journal d Retailing, 70(3), 283-294. https://doi.org/10.1016/0022-4359(94)90037-X

Esbjerg, L., Jensen, B. B., Bech-Larsen, T., Barcellos, M. D., Boztug, Y., \& Grunert, K. G. (2012). An integrative conceptual framework for analyzing customer satisfaction with shopping trip experiences in grocery retailing. Journal of Retailing and Consumer Services, 19, 445-456. https://doi.org/10.1016/j.jretconser.2012.04.006

Euromonitor International. (2018). Consumer Lifestyles in Malaysia (Country Report).

Euromonitor International. (2018a). Retailing in Malaysia.

Ferguson, R. J., Paulin, M., \& Leiriao, E. (2007). Loyalty and Positive Word-of-Mouth. Health Marketing Quarterly, 23(3), 59-77. https://doi.org/10.1080/07359680802086174

Fornell, C., \& Cha, J. (1994). Partial least squares: Advanced methods of marketing research. Advanced Methods of Marketing Research, 52-78. https://doi.org/10.1016/0022-4359(94)90037-X

Fornell, C., \& Larcker, D. F. (1981). Structural equation models with unobservable variables and measurement error: Algebra and statistics. Journal of Marketing Research, 382-388. https://doi.org/10.1177/002224378101800313

Freeman, K., Spenner, P., \& Bird, A. (2012). Three Myths about What Customers Want. Harvard Business Review.

Gold, A. H., Malhotra, A., \& Segars, A. H. (2001). Knowledge management: an organisational capabilities perspective. Journal of Management Information Systems, 18(1), 185-214. https://doi.org/10.1080/07421222.2001.11045669

Gremler, D. D., Gwinner, K. P., \& Brown, S. W. (2001). Generating positive word-of-mouth communication through customer-employee relationships. International Journal of Service Industry Management, 12(1), 44-59. https://doi.org/10.1108/09564230110382763

Hair, J. F., Ringle, C. M., \& Sarstedt, M. (2011). PLS-SEM: Indeed a Silver Bullet. Journal of Marketing Theory and Practice, 19(2), 139-152. https://doi.org/10.2753/MTP1069-6679190202

Hair, J. F., Sarstedt, M., Hopkins, L., \& Kuppelwieser, G. V. (2014). Partial least squares structural equation modeling (PLS-SEM) An emerging tool in business research. European Business Review, 26(2), 106-121. https://doi.org/10.1108/EBR-10-2013-0128

Hanaysha, J. R. (2018). An examination of the factors affecting consumer's purchase decision in the Malaysian retail market. PSU Research Review. https://doi.org/10.1108/PRR-08-2017-0034

Hanson, D., \& Grimmer, M. (2007). The mix of qualitative and quantitative research in major marketing journals, 1993-2002. European Journal of Marketing, 41(1/2), 58-70. https://doi.org/10.1108/03090560710718111

Hellier, P. K., Geursen, G. M., Carr, R. A., \& Rickard, J. A. (2003). Customer repurchase intention A general structural equation model. European Journal of Marketing, 37(11/12), 1762-1800. 
https://doi.org/10.1108/03090560310495456

Hjelmar, U. (2011). Consumers' purchase of organic food products. A matter of convenience and reflexive practices. Appetite, 56, 336-344. https://doi.org/10.1016/j.appet.2010.12.019

Hu, H., \& Jasper, C. R. (2006). Social cues in the store environment and their impact on store image. International Journal of Retail \& Distribution Management, 34(1), 25-48. https://doi.org/10.1108/09590550610642800

Huete-Alcocer, N. (2017). A Literature Review of Word of Mouth and Electronic Word of Mouth: Implications for Consumer Behaviour. Frontiers in Psychology, 8(1256). https://doi.org/10.3389/fpsyg.2017.01256

Hussain, R., \& Ali, M. (2015). Effect of store atmosphere on consumer purchase intention. International Journal of Marketing Studies, 7(2). https://doi.org/10.5539/ijms.v7n2p35

Jiang, L. (Alice), Yang, Z., \& Jun, M. (2013). Measuring consumer perceptions of online shopping convenience. Journal of Service Management, 24(2), 191-214. https://doi.org/10.1108/09564231311323962

Jones, M. A., Mothersbaugh, D. L., \& Beatty, S. E. (2003). The effects of locational convenience on customer repurchase intentions across service types. Journal of Services Marketing, 17(7), 701-712. https://doi.org/10.1108/08876040310501250

Karjaluoto, H., Munnukka, J., \& Kiuru, K. (2016). Brand love and positive word of mouth: the moderating effects of experience and price. Journal of Product \& Brand Management, 25(6), 527-537. https://doi.org/10.1108/ JPBM-03-2015-0834

Kim, Y. K., \& Lee, H. R. (2011). Customer satisfaction using low cost carriers. Tourism Management, 32, 235-243. https://doi.org/10.1016/j.tourman.2009.12.008

Kline, R. B. (2011). Principles and practice of structural equation modelling. New York: Guilford Press.

Kock, N., \& Lynn, G. S. (2012). Lateral Collinearity and Misleading Results in Variance-Based SEM: An Illustration and Recommendations. Journal of the Association for Information Systems, 13(7), 546-580. https://doi.org/10.17705/1jais.00302

Koeck, B., \& Marshall, D. (2015). Word of Mouth Theory Revisited: The Influence of New Actors on Seeding Campaigns. Association for Consumer Research, 43, 374-378.

Lazaris, C., Vrechopoulos, A., Doukidis, G., \& Fraidaki, K. (2015, June). The interplay of omniretailing store atmosphere on consumers purchase intention towards the physical retail store (pp. 1-2). In 12th European, Mediterranean \& Middle Eastern Conference on Information Systems (EMCIS).

Lazarsfeld, P. F., Berelson, B., \& Gaudet, H. (1944). The People's Choice: How the Voter Makes up His Mind in a Presidential Campaign (p. 151). New York: Duell, Sloan and Pearce.

Levy, M., Weitz, B. A., \& Grewal, D. (2015). Retailing Management (9th ed.). McGraw-Hill.

Li, J.-G. T., Kim, J.-O., \& Lee, S. Y. (2009). An empirical examination of perceived retail crowding, emotions, and retail outcomes. The Service Industries Journal, 29(5), 635-652. https://doi.org/10.1080/02642060902720121

Lin, J. S. C., \& Liang, H. Y. (2011). The influence of service environments on customer emotion and service outcomes. Managing Service Quality: An International Journal, 21(4), 350-372. https://doi.org/10.1108/09604521111146243

Lo' pez-Lo' pez, I.'s, Ruiz-de-Maya, S., \& Warlop, L. (2014). When Sharing Consumption Emotions with Strangers Is More Satisfying than Sharing Them with Friends. Journal of Service Research, 1(14).

Machleit, K. A., \& Mantel, S. P. (2001). Emotional response and shopping satisfaction: moderating effects of shopper attributions. Journal of Business Research, 54(2), 97-106. https://doi.org/10.1016/S0148-2963(99)00093-4

Mantrala, M. K., Levy, M., Kahn, B. E., Fox, E. J., Gaidarev, P., Dankworth, B., \& Shah, D. (2009). Why is Assortment Planning so Difficult for Retailers? A Framework and Research Agenda. Journal of Retailing, 85(1), 71-83. https://doi.org/10.1016/j.jretai.2008.11.006

Marques, S. H., Cardoso, M. M., \& Palma, A. P. (2013). Environmental factors and satisfaction in a specialty store. The International Review of Retail, Distribution and Consumer Research, 23(4), 456-474. https://doi.org/10.1080/09593969.2013.785442 
Martos-Partal, M., \& Gonz'alez-Benito,'S. (2013). Studying motivations of store-loyal buyers across alternative measures of behavioural loyalty. European Management Journal, 31, 348-358. https://doi.org/10.1016/j.emj.2013.01.010

Mascarenhas, O. A., Kesavan, R., \& Bernacchi, M. D. (2006). Lasting customer loyalty: a total customer experience approach. Journal of Consumer Marketing, 23(7), 397-405. https://doi.org/10.1108/07363760610712939

Mattila, A. S., \& Wirtz, J. (2001). Congruency of scent and music as a driver of in-store evaluations and behavior. Journal of Retailing, 77, 273-289. https://doi.org/10.1016/S0022-4359(01)00042-2

Menon, K., \& Dubé, L. (2000). Ensuring Greater Satisfaction by Engineering Salesperson Response to Customer Emotions. Journal of Retailing, 76(3), 285-307. https://doi.org/10.1016/S0022-4359(00)00034-8

Mohan, G., Sivakumaran, B., \& Sharma, P. (2012). Store environment's impact on variety seeking behavior. Journal of Retailing and Consumer Services, 19, 419-428. https://doi.org/10.1016/j.jretconser.2012.04.003

Nair, S. R. (2017). Analyzing the relationship between store attributes, satisfaction, patronage- intention and lifestyle in food and grocery store choice behaviour. International Journal of Retail \& Distribution Management. https://doi.org/10.1108/IJRDM-06-2016-0102

Nguyen, D. T., DeWitt, T., \& Russell-Bennett, R. (2012). Service convenience and social servicescape: retail vs hedonic setting. Journal of Services Marketing, 26(4), 265-277. https://doi.org/10.1108/08876041211237569

Oliver, R. L. (1999). Whence customer loyalty? Journal of Marketing, 63, 33-44. https://doi.org/10.2307/1252099

Pan, Y., \& Zinkhan, G. M. (2006). Determinants of retail patronage: a meta-analytical perspective. Journal of Retailing, 82(3), 229-243. https://doi.org/10.1016/j.jretai.2005.11.008

Park, H. H., Jeon, J. O., \& Sullivan, P. (2015). How does visual merchandising in fashion retail stores affect consumers' brand attitude and purchase intention? The International Review of Retail, Distribution and Consumer Research, 25(1), 87-104. https://doi.org/10.1080/09593969.2014.918048

Podsakoff, P. M., MacKenzie, S. B., Lee, J. Y., \& Podsakoff, N. P. (2003). Common Method Biases in Behavioral Research: A Critical Review of the Literature and Recommended Remedies. Journal of Applied Psychology, 88(5), 879-903. https://doi.org/10.1037/0021-9010.88.5.879

Poncin, I., \& Mimoun, M. S. B. (2014). The impact of "e-atmospherics" on physical stores. Journal of Retailing and Consumer Services. https://doi.org/10.1016/j.jretconser.2014.02.013

Pons, F., Giroux, M., Mourali, M., \& Zins, M. (2016). The relationship between density perceptions and satisfaction in the retail setting: mediation and moderation effects. Journal of Business Research, 69(2), 1000-1007. https://doi.org/10.1016/j.jbusres.2015.09.005

Ranaweera, C., \& Prabhu, J. (2003). On the relative importance of customer satisfaction and trust as determinants of customer retention and positive word of mouth. Journal of Targeting, Measurement and Analysis for Marketing, 12(1), 82-90. https://doi.org/10.1057/palgrave.jt.5740100

Reimers, V. (2014). A consumer definition of store convenience (finally). International Journal of Retail \& Distribution Management, 42(4), 315-333. https://doi.org/10.1108/IJRDM-03-2013-0060

Reimers, V., \& Chao, F. (2014). The role of convenience in a recreational shopping trip. European Journal of Marketing, 48(11/12), 2213-2236. https://doi.org/10.1108/EJM-12-2012-0734

Robinson, J. (1976). Interpersonal Influence in Election Campaigns: Two Step-Flow Hypotheses. Public Opinion Quarterly, 40(3), 304. https://doi.org/10.1086/268307

Rowley, J. (2005). The four Cs of customer loyalty. Marketing Intelligence \& Planning, 23(6), 574-581. https://doi.org/10.1108/02634500510624138

Roy, S. K., Shekhar, V., Lassar, W. M., \& Chen, T. (2018). Customer engagement behaviors: The role of service convenience, fairness $\mathrm{T}$ and quality. Journal of Retailing and Consumer Services, 44, 293-304. https://doi.org/10.1016/j.jretconser.2018.07.018

Ruddick, G. (2015). The Four Reasons Why Supermarkets Are Losing Money. Retrieved from https://www.telegraph.co.uk/finance/newsbysector/retailandconsumer/11585366/The-four-reasons-why-sup ermarkets-are-losing-money.html 
Ruiz, D. M., Gremler, D. D., Washburn, J. H., \& Carrión, G. C. (2008). Service value revisited: Specifying a higher-order, formative measure. Journal of Business Research, 61(12), 1278-1291. https://doi.org/10.1016/j.jbusres.2008.01.015

Seiders, K., Voss, G. B., Grewal, D., \& Godfrey, A. L. (2005). Do Satisfied Customers Buy More? Examining Moderating Influences in a Retailing Context. Journal of Marketing, 69, 26-43. https://doi.org/10.1509/jmkg.2005.69.4.26

Sekaran, U., \& Bougie, R. (2008). Research methods for business: A skill building approach (5th ed.). UK: Wiley.

Sirohi, N., Mclaughlin, E. W., \& Wittink, D. R. (1998). A Model of Consumer Perceptions and Store Loyalty Intentions for a Supermarket Retailer. Journal of Retailing, 74(2), 223-245. https://doi.org/10.1016/S0022-4359(99)80094-3

Sivadas, E., \& Jindal, R. P. (2017). Alternative measures of satisfaction and word of mouth. Journal of Services Marketing, 31(2), 119-130. https://doi.org/10.1108/JSM-09-2015-0282

Sullivan, G. M., \& Feinn, R. (2012). Using effect size — or why the P value is not enough. Journal of Graduate Medical Education, 4(3), 279-282. https://doi.org/10.4300/JGME-D-12-00156.1

Terblanche, N. S. (2018). Revisiting the supermarket in-store customer shopping experience. Journal of Retailing and Consumer Services, 40, 48-59. https://doi.org/10.1016/j.jretconser.2017.09.004

Tomazelli, J., Broilo, P. L., Espartel, L. B., \& Basso, K. (2017). The effects of store environment elements on customer-to-customer interactions involving older shoppers. Journal of Services Marketing, 31(4/5), 339-350. https://doi.org/10.1108/JSM-05-2016-0200

Tombs, A., \& McColl-Kennedy, J. R. (2003). Social-Servicescape Conceptual Model. Marketing Theory, 3(4), 447-475. https://doi.org/10.1177/1470593103040785

Troldahl, V., \& Van, D., R. (1965). A New Scale for Identifying Public-Affairs Opinion Leaders. Journalism \& Mass Communication Quarterly, 42(4), 655-657. https://doi.org/10.1177/107769906504200421

Walsh, G., Shiu, E., Hassan, L. M., Michaelidou, N., \& Beatty, S. E. (2011). Emotions, store-environmental cues, store-choice criteria, and marketing outcomes. Journal of Business Research, 64, 737-744. https://doi.org/10.1016/j.jbusres.2010.07.008

Weimann, G. (1982). On the Importance of Marginality: One More Step into the Two-Step Flow of Communication. American Sociological Review, 47(6), 764-773. https://doi.org/10.2307/2095212

\section{Copyrights}

Copyright for this article is retained by the author, with first publication rights granted to the journal.

This is an open-access article distributed under the terms and conditions of the Creative Commons Attribution license (http://creativecommons.org/licenses/by/4.0/). 